\title{
Postmodern Teleological Agents of End in Don DeLilLo's White Noise
}

\author{
Neda Khodadadegan ${ }^{1} \&$ Hardev Kaur Kaur ${ }^{2}$ \\ 1 Taman Sungai Besi Indah, Sec 3, Seri Kembangan, Selangor, Kuala Lumpur, Malaysia \\ 2 English Department, Faculty of Modern Languages and Communication, University Putra Malaysia, Serdang, \\ Selangor Darul Ehsan, Malaysia \\ Correspondence: Neda Khodadadegan, C-2-3, Apartment Desa Saujana, Taman Sungai Besi Indah, Sec 3, 43300, \\ Seri Kembangan, Selangor, Kuala Lumpur, Malaysia. Tel: 60-12-630-7371. E-mail: \\ neda.khodadadegan@gmail.com
}

Received: October 2, 2014 Accepted: November 20, 2014 Online Published: February 12, 2015

doi:10.5539/ass.v11n5p134 URL: http://dx.doi.org/10.5539/ass.v11n5p134

\begin{abstract}
Apocalyptic literature in its secular form is a rich way of depicting a more meaningful fiction about a teleological end. The aim of postmodern apocalyptic literature is to manifest how the need for structure inspires the writers of this genre to use it as a sense-making device in postmodern era. This paper is an analysis of postmodern apocalyptic literary concepts in Richard Don DeLillos' White Noise (1985). The novel represents a sense of apocalypticism in a nuclear age when the fear of an atomic ending is not likely to vanish. The present paper examines the author's depiction of the presence of an apocalyptic world in the postmodern setting of the selected text. It also explores the concept of postmodern apocalyptic deity and its imperfect judgment which calls into question the simplistic depictions of morality. This has been achieved in this study based on a textual analysis as a methodology by applying Elizabeth K. Rosen's study of the genre in her book; Apocalyptic Transformation: Apocalypse and the Postmodern Imagination (2008). Findings of this study show how the absence of a complete destruction in the novel manifests the failure of the only sense-making device in the age of nuclear fear and the everlasting nature of such fears.
\end{abstract}

Keywords: Postmodern apocalyptic literature, apocalyptic world, deity, judgment

\section{Introduction}

Crossing the nightmare of the two World Wars left the residents of America frightened by another challenge of the same sort during the 1980s, in a way that much of the eschatological literature since Hiroshima has focused on the nuclear explosion as the new agent of death. The presence of an everlasting fear of a globally destructive nuclear explosion which has not happened yet causes a feeling of suspense and uncertainty. The complete destruction of the world in traditional apocalyptic literature is replaced with a partial one in the postmodern version of this literature to transfer this feeling of uncertainty.

The etymological root of the word apocalypse is the Greek apocalypsis, meaning uncovering, but the word's relevance to cosmic events is just revealed in its attachment to the Book of Revelation in the New Testament, where it refers to the struggle between good and evil and God's final judgment upon all souls. Traditional apocalyptic literature is considered as a means to comfort people whose lives were overwhelmed by social or historical disruption as well as an attempt by a culture which was deeply confused to understand itself and its own time. Its main purpose was to encourage its audience to maintain faith in hard times and to assure them that their faithfulness would be rewarded and their enemies would be diminished. The element of judgment then is God's final judgment. The guilty who has not only failed unforgivably, but has also demonstrated an inability to right their own wrongs, will be punished as a corrective response (Rosen, 2008, p. xii).

In its secular form, apocalyptic literature is a means for writers to depict the probability of a globally-destructive nuclear war as well as a radical criticism of the political and social constructs in the contemporary world. It is an influential way of narrating fears of catastrophe which have been experienced by the people who are caught in a chaotic society. Postmodern apocalyptic literature has appeared as a result of a cultural corruption. The twentieth century witnessed new sorts of catastrophe such as AIDS epidemic, the destruction of ecosystem, and global 
warming. As a critical means, postmodern apocalyptic literature addresses the declining morality of the modern societies to depict a new sense of ending. Postmodern writers of the apocalyptic genre symbolize the end of morality through the portrayal of more tangible agents of death such as frightening nuclear explosions and the destruction of our ecosystem which lead to a sense of uncertainty about the survival of human beings (Rosen, 2008, p. xix).

Donald Richard DeLillo's work has covered subjects of nuclear war, global terrorism, assassination, and cold war. The publication of White Noise in 1985 brought him widespread recognition due to its direct depictions of the horror of living in a world which is threatened by nuclear explosions. It was followed by Libra in 1988, MaoII in 1992, and Underworld in 1997, all depicting the terror of the End caused by an explosion. Atomic threat lurks in the back of DeLillo's White Noise as the cause of modern anxiety and spiritual malaise. The story takes place in America, sometime late in the twentieth century, most likely around the 1980s; the time in which the novel was written. It explores the conflation of personal and communal apocalypse by depicting a protagonist whose life is dominated by the fear of death. The fear of death becomes communal throughout the story by the appearance of the toxic cloud in the city which seems to threaten the whole city. By depicting the presence of death and nuclear fear, the novel shows itself to be a fine example of postmodern apocalyptic literature.

The selected text depicts a sense of ending in America, showing how the recurrent fear of an atomic event is not likely to disappear after years from the first atomic explosion. The purpose of this study is to examine the presence of an apocalyptic world inhabited by apocalyptic characters and also traditional apocalyptic concepts in the postmodern setting of White Noise. This will be achieved in the present study by applying Rosen's study of postmodern apocalyptic literature which is fully presented in her book; Apocalyptic Transformation: Apocalypse and the Postmodern Imagination (2008). In regard with this, a complete examination of the concepts of apocalyptic world, deity, and judgment will be conducted in the selected text to show how the judgment of imperfect postmodern deity figures calls into question the sense of morality in the contemporary American society during the 1980s. This study seeks to examine how apocalyptic literature as the only sense-making device fails to play its role in a corrupted society where nothing is worth saving and the full purifying end will never happen.

\section{Conceptual Framework}

\subsection{Apocalyptic Literature}

The traditional apocalyptic narrative, known as apocalypse, was formed with the advent of Christianity in the Old Testament. It should be taken into account, though, that the individual components of apocalyptic stories are traced back to the ancient civilizations of Egyptians, Greeks, Vedic Indians, Persians, and Mesopotamians. The Book of Daniel is considered as the most notable apocalyptic story in the Old Testament which depicts the construction of New Jerusalem and the notions of a specific last judgment (Rosen, 2008, p. xiii).

Apocalyptic myth suggests something more than a sense of final order and proves itself to be a means of social criticism. It is usually written by and for the minority that is alienated by the powerful (Rosen, 2008, p. xiii). Since judgment is a crucial element of the traditional apocalyptic literature, it is naturally a vehicle for criticizing individuals' behavior, nation, and cosmos (Rosen, 2008, p. xiii). It is concluded that the original myth is an organizing structure that can create a moral order and also hold the possibility of social criticism in the midst of a bewildering historical moment.

Postmodern apocalyptic literature is a portrayal of social and psychological disruption during the final years of the twentieth century when numerous historical events have caused our apocalyptic fear to grow more acute. Rosen classifies these events on a chronological basis to show how their occurrence has led to the reemergence of the traditional myth of apocalypse. The catastrophe began with the explosion of the nuclear bomb at mid-century. It was followed by HIV/AIDS epidemic that killed twenty two million people and infected another forty two million towards the end of the century. The last event of apocalyptic import is the tragic climatic change that is happening because of global warming. Rosen asserts that the threat of the destruction of the ecosystem is as potentially dangerous as the atomic bomb in a way that it threatens human existence on a global level. The fearful nature of these events and an expanding awareness of their enormity cause a sense of uncertainty about the survival of our planet and the vitality of human future on it (2008, p. xix).

The psychological need to make sense of the disastrous world in which we live stimulates a critical response on the part of artists. The paradox is that the traditional apocalyptic narrative emphasizes that no social reform can cure the corrupted world and assumes that only an absolute, "purifying cataclysm" can make it new and perfect. But what is important in creating postmodern apocalyptic literature is not that writers use the traditional apocalyptic paradigm, but that they manipulate it to make vivid observations of the contemporary world as it 
exists. Hence, the intention is not merely to rework the paradigm, but to use it as a means of social criticism (Rosen, 2008, p. xx).

There has been studies on apocalyptic literature in its postmodern context from a variety of perspectives. In Postmodern Apocalypse: Theory and Cultural Practice at The End (1995), Richard Dellamora provides a collection of apocalyptic narrative and its tone within postmodern culture based on a belief that the uncircumscribed field of narrative at the end of the millennium continues to be structured in relation to apocalypse in its traditional manifestation. Josef Broeck asserts that the apocalyptic genre has distanced itself from its biblical and historical roots due to the fact that there seems to be no agreement on the content, form, or function of apocalyptic writing and thinking in contemporary narratives $(1985$, p. 94). Apocalypse and the Writings on Revelation (1980) by D.H Lawrence is a radical criticism of the political, religious and social in Western civilization. Lawrence's belief in humanity's power to redeem the spiritual values which alone can revive our world makes apocalypse a powerful statement of hope. Such an approach is more apparent in David Ketterer's reinterpretation of New Jerusalem in New Worlds for Old: The Apocalyptic Imagination, Science Fiction, and American Literature (1974, p. 13).

While some critics are more likely to maintain and intensify the element of hope and renewal in their studies of the genre, most contemporary scholars of the field aim to concentrate on the role of the postmodern life and the crisis it has brought about in the creation of postmodern apocalyptic literature. In "No Apocalypse, Not Now", Jacques Derrida has an outstanding argument about the prevalence of nuclear weaponry as frightening forces of destruction that have been stockpiled and capitalized everywhere to establish the very sense of capitalization. Similarly, in his essay "The Whiteness of the Bomb", Ken Cooper notes the recurrent anxiety of western world about nuclear proliferation during the Gulf War in 1991(qtd.in Dellamora, 1995, p. 6). In After the End: Representations of Post-Apocalypse (1999), James Berger sensibly fixes on the idea of crisis when he writes that the sense of perpetual crisis coexists with the notion that the apocalyptic catastrophe has already happened and the apocalyptic writing is only a reminder of some disorienting catastrophe (qtd.in Rosen, 2008, p. 7). In the fourth talk of The Sense of an Ending, "The Modern Apocalypse", Frank Kermode argues that the apocalyptic myth has continued to give us an opportunity to make sense of the world we are living in.He argues that there must be a link between the forms of literature and other ways in which we try to give some kind of order and design to the past, the present and the future (1967, pp. 93-126).

\subsection{Apocalyptic Themes and Motifs}

Rosen's study of postmodern apocalyptic literature points to the writers and filmmakers who clearly have appropriated the apocalyptic myth in a postmodern way. In Apocalyptic Transformation: Apocalypse and the Postmodern Imagination, she mentions that the postmodern writers' major reason for adapting the traditional myth is that, they, too, have used the apocalyptic myth as a vehicle for criticism, bearing in mind that "their postmodern style has profound implications for the apocalyptic paradigm itself" (2008).

Storytellers who have been studied by Rosen in her book are all postmodernists who present their narratives through an apocalyptic framework. They are writers or filmmakers of the end of the twentieth century who use apocalyptic genre as a means for criticism. Rosen shows how they challenge the religious roots of apocalyptic literature in their work by characterizing the three main areas of the traditional version that have been translated into secular terms in postmodern narratives of apocalypse. Deity, judgment, and time are the three main concepts that have been affected when translated. She also argues how the concept of New Jerusalem and apocalyptic world have been presented in a different way in some postmodern apocalyptic narratives.

\subsubsection{Apocalyptic World}

Apocalyptic world which is completely destroyed has also been interpreted in the secular versions of apocalyptic story. Postmodern writers often replace the real world with a figurative one, according to Rosen. In some adaptations, they restrict the world to a specific community or society where the story takes place and not the whole world. In other instances, the authors go further and interpret the world as the mind of an individual. This depiction revolves around the tension between the "perceived world of the narrator and the real world of the story. It is also ended with the destruction of one of these worlds and the creation of the other one (Rosen, 2008, p. xxiii).

\subsubsection{Deity}

In secular adaptations of traditional apocalyptic paradigm, the central figure of Judo-Christian God is replaced with an alternative deity figure. There are several depictions of deity figure in postmodern apocalyptic literature. A human figure might play the role of the deity. This human figure has godlike qualities and possesses the power 
to give and take life. He may also be "omnipotent" or "omniscient" in some other way (Rosen, 2008, p. xxii). The deity figure is not always portrayed in the form of a human being. In some cases, the alternative deity figure takes the form of a particular "apotheosized object, idea, or even ideology" (Rosen, 2008, p. xxii). The significant difference between the Judo-Christian God of apocalyptic myth and the secular humanized deities is that the secular ones are often imperfect characters who are neither absolutely benevolent, nor fully all-knowing.

The significance of such depiction is to manifest that in postmodern secular terms, stronger influences are ambiguity and plurality rather than an absolutist depiction of God (Rosen, 2008, p. xxii). As a result, more than one deity figure is created in secular stories of apocalypse. The authors split the traits of God between their characters, in some cases, emphasizing the God's forgiving side in one character and his wrathful side in another. In other cases, authors combine the roles of "Savior and Antichrist", which are separately portrayed in the Book of Revelation, in one character who is subject to a kind of moral ambivalence. Rosen concludes that: "Where the concept of apocalyptic deity is represented in a person (rather than an abstraction), there is often an accompanying tendency to question what it means to be a god" (2008, p. xxiv).

\subsubsection{Judgment}

The concept of judgment is also affected while being translated into postmodern terms. Postmodernists have always refused to privilege one point of view or culture over another and this matter has made the concept of judgment an ambiguous and amorphous one in postmodern apocalypse (Rosen, 2008, p. xxiv). As explained before, the figurative deities in secular versions of apocalypse are imperfect and thus will have imperfect judgments. Rosen explains the humanized deities in her own terms:

These reconceived deities are often soul-searching, Hamlet-like characters. Unlike the God of the Bible, their moral bearings are sometimes unsteady. They are fully aware of, sometimes even paralyzed by, the moral complexities of the modern world, and they are frequently unsure what is "right" and what is "wrong". Part of what is at stake in postmodern apocalypse is the question of whether objective judgment is possible (2008, p. xxv).

In Apocalyptic Transformation, Rosen provides an analysis of DeLillo's apocalyptic fiction. Chapter six of her study is an examination of apocalyptic features in DeLillo's End Zone, White Noise, Underworld, and Cosmopolis in which she is mainly focused on the apocalyptic characters and their fear of an apocalyptic ending. Her analysis of apocalyptic features on White Noise does not trace the translated motifs of renewal, judgment and deity. The present study suggests an examination of a postmodern apocalyptic setting in DeLillo's White Noise which is a representation of an apocalyptic world. It also analyzes the motifs of deity and judgment in this postmodern setting.

\section{White Noise as a Postmodern Apocalyptic Novel}

White Noise has been called an apocalyptic novel by several critics who all agree about its depiction of a potential destruction and the everlasting fear of death. Dana Philips, for instance, refers to the end of history in analyzing one of the novel's scenes. She expresses how there is an absence of the sense of renewal and regaining the lost things, and how the "apocalyptic products" mark the end of nature and henceforward the end of our culture (qtd.in Bloom, 2003, p. 122). Peter Boxall's study also has a chapter named "Death and the Avant-garde", in which he brings a number of episodes from White Noise to show the novel's depiction of death and the terror it carries into the life of characters. He uses Freud's Beyond the Pleasure Principle (1920) to carry out his examination of these scenes and to manifest how the plot of White Noise in line with every other plot tends to move deathward (2006, p. 111). Stacy Olster, is another critic whose study of White Noise has an analysis of its apocalyptic elements. Despite the two previous essays, Olster argues how consciously the characters are engaged with the disastrous event which threatens their life. By comparing the toxic cloud to the atomic bomb dropped on Hiroshima, Olster explains how the terror of an end has obsessed the characters' mind (qtd.in Duvall, 2008, p. $85)$.

Considering the mentioned studies on DeLillo's White Noise, it can be concluded that the writer portrays the modern American's futile search for the mystery of existence and their unsuccessful attempt to make sense of the meaningless world whose mystery is hopelessly elusive. Though failing to answer the riddles of the cosmos, the novel asks the rigid questions, and in doing so establishes an important original voice in temporary fiction. This is while the writer of this novel is reluctant to discuss his motives behind the creation of his work. In an interview conducted by LeClair, DeLillo says that it is in his nature to keep quiet about most things, even the idea in his work. He believes that an attempt to unravel a work belittles it in a way since it was created as a mystery in the first place (1982, p. 20). 


\subsection{The Representation of an Apocalyptic World}

The first chapter of White Noise, "Waves and Radiation", represents the quotidian life of Gladney family, portraying Jack and Babette quite busy with their five children, mostly of their various previous marriages. In part two of the novel, which is called "Airborne Toxic Event", the Gladney's safety is suddenly destroyed by the chemical spill that forces them to leave their hometown. In DeLillo's disaster novel, nobody dies, though. All the residents of Blacksmith go back to their hometown and look just as they did before this new technological catastrophe, because the effects of the event are invisible to their naked eye. "Dylarama", the last part of the novel, which refers to a new medicine effective in eliminating the fear of death, is an illustration of the new knowledge and science as threats.

In her analysis, Rosen refers to the illegal dumping of radioactive waste as a more striking example of an apocalyptic world $(2008$, p. 6). In White Noise, the physical consequences of ill-managed energy policies are made apparent. The most demonstrating sign of an apocalyptic disaster is the appearance of the toxic cloud in the sky of Blacksmith. The danger of a radioactive exposure is progressively confirmed by observation, the media, and police's warnings. Shockingly, Jack Gladney is exposed to the toxic cloud which is described as: "Packed with chloride, benzenes, phenols, hydrocarbons" $(1999$, p. 139). This scene gives adequate evidence to the fact that White Noise is narrated in an apocalyptic setting where the everlasting nuclear terror is illustrated through the fear of death and the presence of a real atomic disaster.

To refer to the main aim of apocalyptic literature as a device of criticism, it is worth mentioning that while on the surface, the obsession with fear and death seems to occupy a great part of the story, White Noise is "the multiple communications loops of contemporary life in all its manifestations from the personal to the social, the physical body to the body politic" (LeClair, 1987, p. 30). The writer's main concern is the corruption of the postindustrial American society. In "The Figure in the Static", Arthur M. Saltzman shows how in White Noise, language is overflowed by the machines, disks, and data that speak to us and how biology, mathematics, and chemistry have become myth in today's life (1994, p. 810).

DeLillo's depiction of academic realm has been a debating issue since the publication of White Noise. Jack, head of the Hitler Studies Department at College-on-the-Hill, specializes in Hitler. In his world, "Hitler studies appear to be just another subject of the academic discourse, arousing no special passions" (Bloom, 2003, p. 52). In fact, such a portrayal mirrors the scholarly world of the postmodern era, where any possible subject can be accommodated. Mark Conroy's article on White Noise, "From Tombstone to Tabloid: Authority Figure in White Noise", mentions that humanist narrative is an individual's moral authority which is in this case a lecturer who works as a humanist, ironically doing Hitler studies (1994). The phenomenon of Hitler studies has become possible in postmodern America which claims to be the distributer of an ideology of freedom and self-development.

Moral authority in White Noise has also been analyzed by Paul Maltby in 'The Romantic Metaphysics of Don DeLillo'. In his study of morality, Maltby refers to "visionary moments", by which he means "that flash of insight or sudden revelation which critically raises the level of spiritual or self-awareness of a fictional character" (1996, pp. 258-277). Along with Libra and The Names, Maltby analyzes the insights of morality in White Noise by exploring postmodern responses which deny the possibility for a visionary moment in contemporary culture.

Referring to Rosen's study on postmodern apocalyptic literature, the threat of a nuclear disaster has become a part of our collective consciousness. In the novel, it is perceived that the phenomenon of Hitler has not been oppressed completely and has remained alive, as it is in a course catalogue "three hours a week, restricted to qualified seniors" (1999). The corruption in this sense, is perceived in the portrayal of a world replete with immoral possibilities.

\subsection{Personification of Deity Figures}

DeLillo's novel as an apocalyptic story is seen as one of the guiding fictions of our culture, a rich way of altering ideas of disaster and fear of catastrophe into a more mechanical fiction about an ordained structure. In White Noise, the personified deity figure is in a larger scale science, though represented through its minor forms of toxic event, radiation, and Dylarama. It is obvious that Blacksmith residents are afraid of, but mesmerized by the greatness of the toxic event. Science in the hands of power is engineered to kill and thus give man control over the Earth, but it is revealed to threaten its inventors as well as its victims.

Within the apocalyptic framework of White Noise, it is Capitalism that functions as the main deity figure. It is part of a larger system, the interface of a larger consciousness which acts as the personified deity. It shows signs of being an active creator and law giver rather than being merely a form of worship. Lou Canton, in 
"Romanticism and Postmodern Novel: Three Scenes from Don DeLillo's White Noise", argues how some scenes of the novel present evidence for an uncertain romantic who deeply values his personal relations and family, but is fully aware that the world is turning him into a post-industrial who is gradually gaining an inauthentic self (1997). For Stephanie Halldorson, DeLillo's protagonist is, in many ways, the perfect American citizen. His style of life and his family structure are depicted to manifest a naturalized form of presence in a postmodern society. While, through a comparison between DeLillo's and Saul Bellow's hero, Halldorson reveals that they are heroes in the old mode who are playing the role of "a new false hero" (2007, p. 113).

Represented by the dominating images of supermarket and TV, capitalism extends in every corner of the novel's apocalyptic world. Through these mediums, it creates more of itself and in this sense it becomes eternal. Murray who is the criticizer of America's capitalist structure, sees the supermarket as a realm which is not merely replete with physical goods but with messages and communications; a place that recharges individuals' spirituality by advertising psychic data. He believes that all the items in the supermarket are concealed in symbolism and are hidden by layers of cultural material. For Jack, the purchase of goods confers safety through the sense of well-being (1999, p. 18). The furtive menace of television's constant droning is the manner in which advertisements become stuck in the character's brains and the way it distances its viewers from their real life. Since the aim of advertising is to manifest the product as an integral part of large social purposes and processes, the characters cannot escape product clatters even within their own brains: "Coke is it, Coke is it, Coke is it" (1999, p. 56). Now that people everywhere in America have seen the same television shows, they share a wealth of common memories. Unfortunately, these are not memories of actual life, but memories of media manufactured situations and characters. Their collective unconscious is contaminated, filled with media images and advertisements concern over whether or not the toxic cloud will reach them or not.

Mink is a mysterious figure who makes a momentary but significant appearance at the end of White Noise. Long before he actually appears in the text, we know of Mink who is the corrupt project manager behind the drug Dylarama. He has been carrying on an affair with Babette, who believes the pill can ease her irresistible fear of dying. While this character is also mesmerized by the television as the personified deity figure, he himself is the godlike figure in representing scientific apparent savior developments. The deity figure in this respect is personified by the scientist who carries both godlike and anti-Christ characteristics. This scientist, who is morally ambiguous, acts to redeem the human race by engineering a medicine which eliminates the fear of death. Simultaneously, he shows legions of evil spirits by involving and sexually abusing Babette in exchange for the medicine.

This incident in White Noise leads to the temporal appearance of another human deity figure; Jack, who takes the role of the punisher. Faced with the man who has imagined all along as the seducer of his wife, Jack shoots Mink twice in the stomach "for maximum slowness, depth and intensity of pain" (1999, p.349). Jack's plan falters when he places the gun in Mink's hand in an attempt to imply suicide and Mink ends up shooting him in the wrist. Symbolically, Jack tries to kill science as the representative of the greatest deity figure, Capitalism, and science fights back, trying to save itself by injuring his punisher.

By creating both human and object deity figures who all represent the main controlling power in post-Hiroshima America, DeLillo connects the postmodern decentered subjectivity to capitalism. He ties the fragmented consumers to the array of technological and representational apparatuses in the contemporary world. This is achieved by depicting floods of media and shopping centers which disarticulate their participants, replacing them with a new ecstasy of instable inter subjectivity.

\subsection{Imperfect Judgment of Deity Figures}

Rosen, in Apocalyptic Transformation, mentions that postmodern deities are doubting anxious gods, rather than certain decisive ones. Concerning their uncertainty, the decisions they make are believed to be quite different from their biblical progenitors. While in the voice of the biblical apocalyptic God, there is little hint of doubt or regret, secular gods confess to be ambivalent in their thoughts and actions. Though these doubtful deities do not reveal their anxieties in public, they suffer moments of doubt in private $(2008$, p. 30). If the deity figure is personified in the form of an object or an ideology, its unreliable judgment lies in its failure according to Rosen in her discussion of personal/communal apocalyptic link through the novel's focus on capitalist structures as deity figures (2008, p. 166).

DeLillo believes that one of the most attractive features of apocalyptic narrative is judgment which is a different kind of longing; longing for punishment (Rosen, 2008, p. 163). In White Noise, the protagonist is encouraged to take up the role of the deity to punish the guilty. After Babette tells Jack that how Mink has convinced her that the fear of death can be overcome by a pill and how he has seduced her in exchange for the medicine, Jack 
decides to kill him. What makes his decision relevant to postmodern apocalyptic judgment is the fact that he is affected by Murray. The moral simplicity of Jack's revenge is complicated by the fact that he believes himself to be dying from being exposed to the toxic cloud and his own death to be less likely if he kills someone else as Murray has convinced him. It is Murray who gives the theory that justifies the plan: "It's a way of controlling death. A way of gaining the ultimate upper hand. Be the killer for a change. Let someone else be the dier. Let him replace you, theoretically, in that role. You can't die if he does. He dies, you live" (1999, p. 318).

Jack is certain to punish the guilty but the only reason why he attempts this role is that there is someone he wants to punish. The doubtfulness of the deity figure is revealed when he finds himself uncertain about the real motivation behind this punishment. It is not clear whether Jack is going to punish Mink for seducing his wife or for the bad news. He is doubting in a sense that he does not know whether he is there for punishing Mink or asking him for the pill to eliminate his own fear of death (1999, pp. 334-338).

Rosen in her analysis on White Noise asserts that the novel's focus is on capitalism, where the writer has found connections tangible rather than ethereal. She explains that in capitalist societies, and particularly in the present global economy, every minor being is connected to an extremely powerful economic entity and this could cause an economic meltdown $(2008$, p. 166). Rosen's explanation turns our attention to capitalism as the grand deity figure in DeLillo's novel and the portrayal of its judgment. As it has been explained before, this personified deity figure is represented in the form of the supermarket and the television in White Noise and its unreliable judgment is depicted through its failure to play its supportive role. In "Closing the Loop", LeClair argues that White Noise's center is the supermarket where numerous scenes in the novel occur. According to him, the supermarket stands as a symbol of a physical magnitude that can help people master their fear of death. For the Gladney, the purchase of goods confers safety.

A more astute look at the supermarket products uncovers its unreliable judgment. The poison in its products contrasts the feeling of safety it brings and it seems to have a deeper meaning. It initially gives its consumers a sense of physical expansiveness by which they soften the texture of the real danger. Jack who is obsessed with the fear of death, collects layers of supermarket objects to cope with his fear through materialistic devices. The products fail to give Jack a sense of security and his fear of death is intensified. He rampages through his house, finds the objects and throws them away (1999, p. 298).

Another phase of capitalism which fails to bring security and conveys a feeling of doubt and unreliability is television in the society of White Noise. Television programming is not only a simplistic threat, or a reductive conditioning agent that DeLillo associates with advertising. It seems to have more complex binary effects: conditioning and comforting, distorting and informing, even becoming later a source of mystery. At one level, the media offers Babette and Jack a comforting background noise, evidence beneath their conscious threshold that they are connected to a mass of other listeners and are not alone. On the other hand, it becomes the source of "fears and secret desires" (1999, p. 95) since it is the main source of giving news and information about catastrophes and coming threats.

The untrustworthiness of science as an imperfect deity figure is directly stated by Murray, discussing modern death that applies as well to modern science: "The more we learn, the more it grows. Is this some law of physics? Every advance in knowledge and technique is matched by a new kind of death, a new strain. Death adapts, like a viral agent. Is it a law of nature" (1999, p. 164)? This interpretation, in White Noise, matches the airborne toxic event as a new form of death to which Jack has been exposed. It also can be applied to Dylar pill Babette takes to ward off her fear of death which fails to work but seems to be addictive. In the twilight of narratives of immortality, no rational paradigm presents itself as reliable to the Gladney, least of all one of science or technology. Instead, the products of modern technology become themselves fetish objects of the miracle drugs and the electronic media. Indeed, it is an emphasis upon personhood, upon the physical as prerequisite for spiritual authority and the mere fact that one's positioning by the mass media and science is itself the sign of subjectivity.

\section{Conclusion}

The apocalyptic world which in secular terms is replaced with a destructed society is apparent in the way the society of White Noise is portrayed. Signs of a physical destruction are firstly professed in the novel through the portrayal of its protagonists and secondly through the environmental damages. Preoccupation with death brings the element of mystery, creating a space for a nuclear disaster that does not happen in the novel. Apocalyptic literature as a means for social and political criticism is in need of a world which is morally corrupted. In White Noise the corruption is seen in the portrayal of familial structures, mainly referring to both Jack's and Babette's various previous marriages and the behavior of their children who, through media, are inappropriately and 
unavoidably exposed to all sorts of knowledge and information. It is also seen through the immoral possibilities of today's world, referring to Hitler Studies, as Jack's occupation.

In White Noise, the concept of deity is portrayed in the form of human figures. In White Noise, there are only temporary human godlike figures who take the role for a short period of time. Mink, as an example, becomes the representative of science in inventing a medicine that eliminates the fear of death. In this sense, he is an agent of the main deity figure, capitalism. Even though, the novel presents human deity figures, its major deity is an object standing for an ideology to represent apocalyptic literature as a device for criticism. In White, atomic bomb becomes a faith to people in its everlasting presence they believe. The capitalist system as a deity figure is depicted in the form of its three main agents; supermarket, television, and science.

Since the deities in the secular depictions of White Noise are ambivalent in their thoughts and actions, their judgment becomes imperfect and unreliable. Jack, in White Noise, is longing for punishment, but this sense has been imposed on him by Murray. The manipulation of this deity figure becomes obvious when the reader finds him doubtful about the reason for punishment. The unreliability of his judgment lies in the failure of punishment. Failed to fulfil the only role he has taken as a deity figure, Jack is disillusioned by a nun who confesses that none of them believes in such thing as God and this questions all his faith in morality and the presence of a protective God in such an unsafe world.

There is no doubt that the major deity figures of the two novels are unreliable in their judgment since they fail to play their role as a protective godlike figures. The supermarket which conveys a sense of wealth and physical expansion to its customers, is revealed to have poison in its products and becomes the reason of a character's death, thence fails to secure its participants. Television which in the beginning, conveys a feeling of safety through connecting all its audience, becomes the main medium in giving news of threat and disaster. The hazard of television becomes serious when it distances its audience from reality by conveying a sense of amusement in reporting disastrous events and blinding them through advertisements.

The complete destruction never happens in White Noise. It emphasizes on a never coming destruction and gives no suggestions of the presence of a better world to be inherited by the faithful in the end. Jack Gladney does not die from being exposed to the chemical cloud. The final scene of the novel which is quite different from apocalypse as a myth, suggests a new interpretation of the whole postmodern paradigm.

Lack of ending means lack of renewal which in traditional apocalyptic narratives is demonstrated in New Jerusalem. The complete destruction as a cleansing event does not occur here, suggesting that the corrupt world can never be purified. Rosen suggests that "New Jerusalem and the hope it symbolizes only exist outside reality"; it exists in the character's mind $(2008$, p. 80$)$. It can be concluded that lack of a purifying end exposes the apocalyptic paradigm through which the characters are able to make sense of a chaotic world. When apocalypse is removed, a clear sense of good and evil is lost. In White Noise, concepts of apocalyptic world, deity, and judgment are perceived, bearing in mind that its portrayal does not follow similar approaches and is different in some aspects.

\section{References}

Berger, J. (1999). After the end: Representations of post-apocalypse. Minneapolis: University of Minneapolis Press.

Bloom, H. (2003). Bllom's modern critical interpretations. Don DeLillo's white noise. Broomall: Chelsea House Publishers.

Boxall, P. (2006). Don DeLillo: The possibility of fiction. Oxon: Routledge.

Broeck, J. (1985). The Apocalyptic Imagination in America; Recent Criticism. The kritikon litterarum, 14, 89-94.

Canton, L. F. (1997, September). Romanticism and the Postmodern Novel: Three Scenes from Don DeLillo's White Noise." English language notes, 35, 38-48. http:// connection.ebscohost.com

Conroy, M. (1994). From Tombstone to Tabloid: Authority Figured in White Noise. Critique, 35(2), 97-110.

DeLillo, R. D. (1999). White noise. New York: Penguin Books.

Dellamora, R. (1995). Postmodern apocalypse: Theory and cultural practice at the end. Pennsylvania: University of Pennsylvania Press.

Derrida, J., Porter, C., \& Lweis, P. (1984). No Apocalypse, Not Now (Full Speed Ahead, Seven Missiles, Seven Missives. Diacritics (pp. 20-31). Retrieved from http://link.jstor.org/0300-7162/28198422

Duvall, J. (1994). The (Super) marketplace of Images: Television as Unmediated Mediatio in DeLillo's White 
Noise. Arizona Quarterly: A journal of American literature, culture, and theory, 50(3), 127-153. Retrieved from http://muse.jhu.edu

Duvall, J. N.( 2008). The cambridge companion to Don DeLillo. New York: Cambridge University Press.

Halldorson, S. S. (2007). The hero in contemporary American fiction: The works of Saul Bellow and Don DeLillo. New York: Palgrave Macmillan.

Kermode, F. (1967). The sense of an ending. Oxford: Oxford University.

Ketterer, D. (1974). New world for old: The apocalyptic imagination, science fiction, and American literature. Bloomington: Indiana University.

Lawrence, D. H. (2001). Apocalypse and the writings on revelation. Cambrigde: Cambridge University Press.

Le Clair, T. (n. d.). In the loop: Don DeLillo and the systems novel. Urbana: University of Illinois Press.

LeClair, T. (1987). An Interview with Don DeLillo. Contemporary literature, 19-31. http://dx.doi.org/10.2307/1208140

Maltby, P. (1996). The Romantic Metaphysics of Don DeLillo. Contemporary literature, 37(2), $258-77$. http://dx.doi.org/10.2307/1208875

Rosen, E. K. (2008). Apocalyptic transformation: Apocalypse and the postmodern imagination. Lanham: Lexington Books.

Saltzman, A. M. (1994). The Figure in the Static: White Noise. Modern fiction studies, 40(4), 807-826. Retrieved from http://muse.jhu.edu/

Wilcox, L. (1991). Baudrillard, DeLillo's "White Noise", and the End of Heroic Narrative. Contemporary Literature, 32, 346-365. http://dx.doi.org/10.1353/mfs.1994.0049

\section{Copyrights}

Copyright for this article is retained by the author(s), with first publication rights granted to the journal.

This is an open-access article distributed under the terms and conditions of the Creative Commons Attribution license (http://creativecommons.org/licenses/by/3.0/). 